\title{
Penjadwalan Produksi Untuk Meminimalkan Waktu Produksi Dengan Menggunakan Metode Branch And Bound
}

\author{
Nunung Indra Lesmana \\ Jurusan Teknk Industri, Fakultas Teknik, Universitas Muhammadiyah Malang \\ Jl. Raya Tlogomas 246 Malang \\ Surel: indra.nunung@gmail.com
}

\begin{abstract}
Scheduling is the process of organizing, selecting and timing of the use of existing resources to produce output as expected within the expected time too. Problems faced by the company is determining the minimal production scheduling, as in the case of the production of the company in March, May and August 2015, delays occurred up to three business days, or approximately 14\% compared to normal production time per month. The results of this study indicate if using methods Branch and Bound, the more processing time than the method the company trimmed. for example, in February 2016 when using the method of the company, the turnaround time is obtained 10584.385 minutes, whereas if the company uses Branch and Bound method can be reduced completion time of 789.66 minutes so that it becomes 9794.719 minutes, or 1.8 days faster than using companies.
\end{abstract}

Key words : production scheduling, flow shop, branch and bound, makespan.

\begin{abstract}
Abstrak
Penjadwalan merupakan proses pengorganisasian, pemilihan, dan penentuan waktu penggunaan sumber daya yang ada untuk menghasilkan output seperti yang diharapkan dalam waktu yang diharapkan juga. Permasalahan yang dihadapi oleh perusahaan adalah menentukan penjadwalan produksi yang minimal, seperti dalam kasus produksi perusahaan di bulan maret, mei, dan agustus 2015, keterlambatan terjadi sampai dengan tiga hari kerja atau sekitar $14 \%$ dibandingkan dengan waktu normal produksi per bulan. Hasil dari penelitian ini menunjukkan jika menggunakan metode Branch and Bound maka waktu pengerjaan lebih singkat daripada menggunakan metode perusahaan. misalnya pada bulan Februari 2016 jika menggunakan metode perusahaan maka waktu penyelesaian yang didapat adalah 10.584,385 menit, sedangkan jika menggunakan metode Branch and Bound waktu penyelesaian bisa diperkecil sebesar 789,66 menit sehingga menjadi 9.794,719 menit, atau 1,8 hari lebih cepat dibanding dengan menggunakan metode perusahaan.
\end{abstract}

Kata kunci : penjadwalan produksi, flow shop, branch and bound, makespan.

\section{Pendahuluan}

Penjadwalan merupakan alat ukur bagi perencanaan agregat. Pesanan-pesanan actual pada tahap ini ditugaskan pertama kalinya pada sumber daya tertentu, kemudian dilakukan pengurutan kerja pada tiap-tiap pusat pemrosesan sehingga dicapai optimasi utilitas kapasitas yang ada. Pada penjadwalan ini permintaan akan produk-produk yang tertentu (jenis dan jumlah) dari MPS akan ditugaskan pada pusat-pusat pemrosesan[1].

Menurut Haming and Nurnajamuddin [2] penjadwalan adalah pengalokasian sumber daya dari waktu ke waktu untuk menunjang pelaksanaan dan penyelesaian suatu aktivitas pengerjaan spesifik. Penentuan alokasi sumber daya perusahaan (sumber daya manusia, sumber daya kapasitas dan peralatan produksi atau mesin-mesin, dan waktu) ditunjukkan untuk mewujudkan sasaran penggunaan sumber daya secara efektif dan 
efisien, sekaligus menghasilkan keluaran (output) yang tepat jumlah, tepat waktu, dan tepat kualitas [3-5].

Masalah utama yang dihadapi oleh perusahaan adalah menentukan penjadwalan produksi yang minimal. Tujuan penulisan makalah ini adalah untuk menguraikan salah satu metode dalam meminimalkan waktu penjadwal produksi untuk jenis produk Maxi, Matras, dan Twin. Perusahaan menggunakan metode FIFO dalam proses produksinya, yang artinya job yang dikerjakan terlebih dahulu adalah job yang pertama datang[6-9]. Dengan begitu, penyelesaian job akan membutuhkan waktu yang lama. Seperti dalam kasus produksi dibulan maret, mei, dan agustus 2015 keterlambatan terjadi satu sampai tiga hari kerja atau sekitar $14 \%$ dari waktu normal selama satu bulan. Atas dasar permasalahan tersebut perusahaan memerlukan sebuah metode penjadwalan yang baik untuk sistem operasinya. Berdasarkan pada permasalahan di atas dan juga pada penelitian-penelitian sebelumnya perlu dilakukan suatu penjadwalan produksi agar bisa meminimalkan waktu penyelesaian produksi, sehingga perusahaan dapat memproduksi produk sesuai dengan waktu yang ditentukan, sehingga mesin dapat digunakan dengan optimal. Pada penelitian ini, metode penjadwalan produksi yang digunakan adalah branch and bound.

\section{Metode Penelitian}

\section{Langkah-Langkah Penelitian}

1. Membuat Jadwal Produksi Metode Perusahaan (FIFO)

Memilih pekerjaan berdasarkan yang datang dahulu, itu yang diproses[10]. Dengan menggunakan aturan ini, proses pekerjaan tersebut tiba pada fasilitas yang bersangkutan[3].

2. Membuat Jadwal Produksi Dengan Metode Usulan

Metode Branch and Bound merupakan salah satu metode yang baik untuk digunakan dalam menyelesaikan masalah kombinasi dengan menggunakan strategi pengurangan jumlah perhitungan yang dilakukan, dalam metode ini terdapat dua prosedur dasar yaitu branching (percabangan) dan bounding (pembatasan). Branching adalah proses pembagian atau percabangan satu masalah yang besar atau rumit menjadi dua atau lebih sub masalah yang lebih kecil atau sederhana, sedangkan bounding adalah proses menghitung batas bawah solusi optimal dari sub masalah yang diperoleh dari percabangan. [11].

Dalam menyelesaikan masalah penjadwalan pada system produksi yang bersifat flow shop, menggunakan pendekatan Algoritma Branch and Bound untuk aliran produksi flow shop yang dikembangkan oleh Ignall and Scharge, dan Lomnicki. Adapun perhitungan untuk tiga mesin adalah sebagai berikut [12]:

Memilih job yang terlebih dahulu dikerjakan,kemudian menghitung lower bound di mesin 1 (b1), lower bound di mesin 2 (b2), dan lower bound di mesin 3 (b3)

$$
b 1=q 1+\sum_{j \epsilon \sigma} t j 1+\min _{j \in \sigma}\{t j 2+t j 3\}
$$

Kemudian menghitung b untuk mesin ke dua

$b 2=q 2+\sum_{j \in \sigma} t j 2+\max _{j \in \sigma}\{t j 3\}$

Yang terakhir menghitung untuk mesin ke tiga

$b 3=q 3+\sum_{j \epsilon \sigma} t j 3$

Kemudian menentukan nilai $\mathrm{B}$

$B=\max \{b 1, b 2, b 3\}$ 
Lakukan langkah yang sama untuk menghitung urutan pengerjaan yang berbeda dan pilih $\mathrm{B}$ terkecil, atau jika perhitungan penjadwalan dengan menggunakan $\mathrm{m}$ mesin maka dapat memakai rumus

$$
\begin{aligned}
& b i=q i+\sum_{J \in \sigma} t J i+\min _{J \in \sigma}\left\{\sum_{i=i+1}^{m} t J i\right\} \\
& B K=\max _{i}\{b i\} \\
& M=\min _{K}\{B K\}
\end{aligned}
$$

Dimana :

bi = lower bound, adalah hasil perhitungan dari nilai batas bawah pada mesin i.

qi $=$ jumlah completion time yang terakhir pada mesin $\mathrm{i}$.

$\sigma=$ job yang belum dijadwalkan.

tij = waktu proses job j pada mesin $\mathrm{i}$.

$\mathrm{m}=$ banyaknya tahapan pengerjaan di mesin.

$\mathrm{n}=$ banyaknya $j o b$

$\mathrm{BK}=$ max lower bound untuk partial sequencing ke-K

$\mathrm{M}=\min$ lower bound dari job $\mathrm{j}$.

\section{Hasil dan Pembahasan}

\subsection{Penjadwalan Awal Perusahaan}

Pada penelitian ini solusi awal metode yang diterapkan pada perusahaan untuk urutan pekerjaan adalah dengan subjektifitas, dan urutannya adalah job 1-2-3-4-5-6 yang terdiri dari Maxi ukuran 120 x $200 \mathrm{~cm}$ (J1), Maxi ukuran 160 x $200 \mathrm{~cm}$ (J2), Maxi ukuran 180 x $200 \mathrm{~cm}(\mathrm{~J} 3)$, dan Twin ukuran 160 x $200 \mathrm{~cm}(\mathrm{~J} 6)$. Untuk lebih jelasnya dapat dilihat

\begin{tabular}{|c|c|c|c|c|c|c|c|c|c|c|c|}
\hline \multirow{2}{*}{$\begin{array}{c}\text { Urutan } \\
\text { Ke- }\end{array}$} & \multicolumn{3}{|c|}{ Urutan } & \multirow{2}{*}{$\begin{array}{l}\text { Urutan } \\
\text { Ke- }\end{array}$} & \multicolumn{3}{|c|}{ Urutan } & \multirow{2}{*}{$\begin{array}{l}\text { Urutan } \\
\text { Ke- }\end{array}$} & \multicolumn{3}{|c|}{ Urutan } \\
\hline & $J o b$ & $\mathrm{Ke}-$ & $J o b$ & & $J o b$ & $\mathrm{Ke}-$ & $J o b$ & & $J o b$ & $\mathrm{Ke}-$ & $J o b$ \\
\hline 1 & J1.1 & 9 & J2.1 & 17 & J3.1 & 25 & $\mathrm{~J} 4.2$ & 33 & J5.2 & 41 & J6.3 \\
\hline 2 & J1.2 & 10 & J2.2 & 18 & J3.2 & 26 & J4.3 & 34 & J5.3 & 42 & J6.4 \\
\hline 3 & J1.3 & 11 & J2.3 & 19 & J3.3 & 27 & $\mathrm{~J} 4.4$ & 35 & J5.4 & 43 & J6.5 \\
\hline 4 & J1.4 & 12 & J2.4 & 20 & J3.4 & 28 & $\mathrm{~J} 4.5$ & 36 & J5.5 & 44 & J6.6 \\
\hline 5 & J1.5 & 13 & J2.5 & 21 & J3.5 & 29 & J4. 6 & 37 & J5. 6 & 45 & J6.7 \\
\hline 6 & J1.6 & 14 & J2. 6 & 22 & J3.6 & 30 & J4.7 & 38 & J5.7 & 46 & J6.8 \\
\hline 7 & J1.7 & 15 & J2.7 & 23 & J3.7 & 31 & $\mathrm{~J} 4.8$ & 39 & J6.1 & & \\
\hline 8 & J1.8 & 16 & J2.8 & 24 & J4.1 & 32 & J5.1 & 40 & J6.2 & & \\
\hline
\end{tabular}
pada tabel 1:

Tabel 1 Urutan Pengerjaan dengan Metode Perusahaan

Dari tabel 2 dapat disimpulkan bahwa dengan menggunakan metode FIFO (Firs In Firs Out) makespan yang dihasilkan sebesar 10584,,39 menit.

\subsection{Penjadwalan Dengan Metode Branch and Bound}

Berikut perhitungan penjadwalan dengan menggunakan Metode Branch and Bound, pada perhitungan metode Branch and Bound ini menggunakan bantuan program Microsoft Excel dan hasil perhitungannya adalah sebagai berikut :

Iterasi 1 
Tabel 2 a Perhitungan Makespan dengan metode perusahaan (menit)

\begin{tabular}{|c|c|c|c|c|c|c|c|c|c|c|c|c|c|c|c|}
\hline \multirow{2}{*}{ Job } & \multirow{2}{*}{ Batch } & \multicolumn{7}{|c|}{ Mulai } & \multicolumn{7}{|c|}{ Selesai } \\
\hline & & M1 & M2 & M3 & M4 & M5 & M6 & M7 & M1 & M2 & M3 & M4 & M5 & M6 & M7 \\
\hline \multirow{7}{*}{ J1 } & J1.1 & 0,00 & 52,35 & 128,10 & 128,10 & 128,10 & 128,10 & 333,60 & 52,35 & 128,10 & 128,10 & 128,10 & 128,10 & 333,60 & 613,60 \\
\hline & $\mathrm{J} 1.2$ & 52,35 & 128,10 & 203,85 & 203,85 & 203,85 & 203,85 & 613,60 & 104,70 & 203,85 & 203,85 & 203,85 & 203,85 & 409,35 & 893,60 \\
\hline & J1.3 & 104,70 & 203,85 & 279,60 & 279,60 & 279,60 & 279,60 & 893,60 & 157,05 & 279,60 & 279,60 & 279,60 & 279,60 & 485,10 & 1173,60 \\
\hline & J1.5 & 209,40 & 355,35 & 431,10 & 431,10 & 431,10 & 690,60 & 1453,60 & 261,75 & 431,10 & 431,10 & 431,10 & 431,10 & 896,10 & 1733,60 \\
\hline & J1.6 & 261,75 & 431,10 & 506,85 & 506,85 & 506,85 & 896,10 & 1733,60 & 314,10 & 506,85 & 506,85 & 506,85 & 506,85 & 1101,60 & 2013,60 \\
\hline & J1.7 & 314,10 & 506,85 & 582,60 & 582,60 & 582,60 & 1101,60 & 2013,60 & 366,45 & 582,60 & 582,60 & 582,60 & 582,60 & 1307,10 & 2293,60 \\
\hline & $\mathrm{J} 1.8$ & 366,45 & 582,60 & 655,32 & 655,32 & 655,32 & 1307,10 & 2293,60 & 416,71 & 655,32 & 655,32 & 655,32 & 655,32 & 1504,38 & 2562,40 \\
\hline \multirow{7}{*}{$\mathrm{J} 2$} & $\mathrm{~J} 2.2$ & 490,81 & 754,32 & 853,32 & 853,32 & 853,32 & 1706,38 & 2852,40 & 564,91 & 853,32 & 853,32 & 853,32 & 853,32 & 1908,38 & 3142,40 \\
\hline & J2.3 & 564,91 & 853,32 & 952,32 & 952,32 & 952,32 & 1908,38 & 3142,40 & 639,01 & 952,32 & 952,32 & 952,32 & 952,32 & 2110,38 & 3432,40 \\
\hline & $\mathrm{J} 2.4$ & 639,01 & 952,32 & 1051,32 & 1051,32 & 1051,32 & 2110,38 & 3432,40 & 713,11 & 1051,32 & 1051,32 & 1051,32 & 1051,32 & 2312,38 & 3722,40 \\
\hline & J2.5 & 713,11 & 1051,32 & 1150,32 & 1150,32 & 1150,32 & 2312,38 & 3722,40 & 787,21 & 1150,32 & 1150,32 & 1150,32 & 1150,32 & 2514,38 & 4012,40 \\
\hline & J2.6 & 787,21 & 1150,32 & 1249,32 & 1249,32 & 1249,32 & 2514,38 & 4012,40 & 861,31 & 1249,32 & 1249,32 & 1249,32 & 1249,32 & 2716,38 & 4302,40 \\
\hline & J2.7 & 861,31 & 1249,32 & 1348,32 & 1348,32 & 1348,32 & 2716,38 & 4302,40 & 935,41 & 1348,32 & 1348,32 & 1348,32 & 1348,32 & 2918,38 & 4592,40 \\
\hline & J2.8 & 935,41 & 1348,32 & 1401,78 & 1401,78 & 1401,78 & 2918,38 & 4592,40 & 975,42 & 1401,78 & 1401,78 & 1401,78 & 1401,78 & 3027,46 & 4749,00 \\
\hline \multirow{6}{*}{ J3 } & J3.1 & 975,42 & 1076,02 & 1401,78 & 1401,78 & 1401,78 & 3027,46 & 4749,00 & 1076,02 & 1201,27 & 1401,78 & 1401,78 & 1401,78 & 3228,96 & 5044,00 \\
\hline & J3.2 & 1076,02 & 1201,27 & 1401,78 & 1401,78 & 1401,78 & 3228,96 & 5044,00 & 1176,62 & 1326,52 & 1401,78 & 1401,78 & 1401,78 & 3430,46 & 5339,00 \\
\hline & J3.3 & 1176,62 & 1326,52 & 1451,77 & 1451,77 & 1451,77 & 3430,46 & 5339,00 & 1277,22 & 1451,77 & 1451,77 & 1451,77 & 1451,77 & 3631,96 & 5634,00 \\
\hline & J3.5 & 1377,82 & 1577,02 & 1702,27 & 1702,27 & 1702,27 & 3833,46 & 5929,00 & 1478,42 & 1702,27 & 1702,27 & 1702,27 & 1702,27 & 4034,96 & 6224,00 \\
\hline & J3.6 & 1478,42 & 1702,27 & 1827,52 & 1827,52 & 1827,52 & 4034,96 & 6224,00 & 1579,02 & 1827,52 & 1827,52 & 1827,52 & 1827,52 & 4236,46 & 6519,00 \\
\hline & J3.7 & 1579,02 & 1827,52 & 1935,24 & 1935,24 & 1935,24 & 4236,46 & 6519,00 & 1665,54 & 1935,24 & 1935,24 & 1935,24 & 1935,24 & 4409,75 & 6772,70 \\
\hline \multirow{8}{*}{$\mathrm{J} 4$} & $\mathrm{~J} 4.1$ & 1665,54 & 1935,24 & 2032,74 & 2366,24 & 2619,24 & 4409,75 & 6772,70 & 1739,64 & 2032,74 & 2366,24 & 2619,24 & 2872,24 & 4409,75 & 6772,70 \\
\hline & $\mathrm{J} 4.2$ & 1739,64 & 2032,74 & 2366,24 & 2699,74 & 2952,74 & 4409,75 & 6772,70 & 1813,74 & 2130,24 & 2699,74 & 2952,74 & 3205,74 & 4409,75 & 6772,70 \\
\hline & $\mathrm{J} 4.3$ & 1813,74 & 2130,24 & 2699,74 & 3033,24 & 3286,24 & 4409,75 & 6772,70 & 1887,84 & 2227,74 & 3033,24 & 3286,24 & 3539,24 & 4409,75 & 6772,70 \\
\hline & J4.4 & 1887,84 & 2227,74 & 3033,24 & 3366,74 & 3619,74 & 4409,75 & 6772,70 & 1961,94 & 2325,24 & 3366,74 & 3619,74 & 3872,74 & 4409,75 & 6772,70 \\
\hline & J4.5 & 1961,94 & 2325,24 & 3366,74 & 3700,24 & 3953,24 & 4409,75 & 6772,70 & 2036,04 & 2422,74 & 3700,24 & 3953,24 & 4206,24 & 4409,75 & 6772,70 \\
\hline & J4.6 & 2036,04 & 2422,74 & 3700,24 & 4033,74 & 4286,74 & 4539,74 & 6772,70 & 2110,14 & 2520,24 & 4033,74 & 4286,74 & 4539,74 & 4539,74 & 6772,70 \\
\hline & $\mathrm{J} 4.7$ & 2110,14 & 2520,24 & 4033,74 & 4367,24 & 4620,24 & 4873,24 & 6772,70 & 2184,24 & 2617,74 & 4367,24 & 4620,24 & 4873,24 & 4873,24 & 6772,70 \\
\hline & J4.8 & 2184,24 & 2617,74 & 4367,24 & 4493,97 & 4590,11 & 4686,25 & 6772,70 & 2212,39 & 2654,79 & 4493,97 & 4590,11 & 4686,25 & 4686,25 & 6772,70 \\
\hline \multirow{7}{*}{ J5 } & J5.1 & 2212,39 & 2654,79 & 4493,97 & 4877,47 & 5130,47 & 5383,47 & 6772,70 & 2312,99 & 2780,04 & 4877,47 & 5130,47 & 5383,47 & 5383,47 & 6772,70 \\
\hline & J5.2 & 2312,99 & 2780,04 & 4877,47 & 5260,97 & 5513,97 & 5766,97 & 6772,70 & 2413,59 & 2905,29 & 5260,97 & 5513,97 & 5766,97 & 5766,97 & 6772,70 \\
\hline & J5.3 & 2413,59 & 2905,29 & 5260,97 & 5644,47 & 5897,47 & 6150,47 & 6772,70 & 2514,19 & 3030,54 & 5644,47 & 5897,47 & 6150,47 & 6150,47 & 6772,70 \\
\hline & J5.4 & 2514,19 & 3030,54 & 5644,47 & 6027,97 & 6280,97 & 6533,97 & 6772,70 & 2614,79 & 3155,79 & 6027,97 & 6280,97 & 6533,97 & 6533,97 & 6772,70 \\
\hline & J5.5 & 2614,79 & 3155,79 & 6027,97 & 6411,47 & 6664,47 & 6917,47 & 6917,47 & 2715,39 & 3281,04 & 6411,47 & 6664,47 & 6917,47 & 6917,47 & 6917,47 \\
\hline & J5.6 & 2715,39 & 3281,04 & 6411,47 & 6794,97 & 7047,97 & 7300,97 & 7300,97 & 2815,99 & 3406,29 & 6794,97 & 7047,97 & 7300,97 & 7300,97 & 7300,97 \\
\hline & J5.7 & 2815,99 & 2908,55 & 6794,97 & 7147,79 & 7380,55 & 7613,31 & 7613,31 & 2908,55 & 3023,78 & 7147,79 & 7380,55 & 7613,31 & 7613,31 & 7613,31 \\
\hline
\end{tabular}


Tabel 2 b (Lanjutan)

\begin{tabular}{|c|c|c|c|c|c|c|c|c|c|c|c|c|c|c|c|}
\hline \multirow{2}{*}{ Job } & \multirow{2}{*}{ Batch } & \multicolumn{7}{|c|}{ Mulai } & \multicolumn{7}{|c|}{ Selesai } \\
\hline & & M1 & M2 & M3 & M4 & M5 & M6 & M7 & M1 & M2 & M3 & M4 & M5 & M6 & M7 \\
\hline \multirow{8}{*}{ J6 } & J6.1 & 2908,55 & 3057,05 & 7147,79 & 7481,29 & 7734,29 & 7987,29 & 8194,79 & 3057,05 & 3256,55 & 7481,29 & 7734,29 & 7987,29 & 8194,79 & 8484,79 \\
\hline & $\mathrm{J} 6.2$ & 3057,05 & 3256,55 & 7481,29 & 7814,79 & 8067,79 & 8320,79 & 8528,29 & 3205,55 & 3456,05 & 7814,79 & 8067,79 & 8320,79 & 8528,29 & 8818,29 \\
\hline & J6.3 & 3205,55 & 3456,05 & 7814,79 & 8148,29 & 8401,29 & 8654,29 & 8861,79 & 3354,05 & 3655,55 & 8148,29 & 8401,29 & 8654,29 & 8861,79 & 9151,79 \\
\hline & J6.4 & 3354,05 & 3655,55 & 8148,29 & 8481,79 & 8734,79 & 8987,79 & 9195,29 & 3502,55 & 3855,05 & 8481,79 & 8734,79 & 8987,79 & 9195,29 & 9485,29 \\
\hline & J6.5 & 3502,55 & 3855,05 & 8481,79 & 8815,29 & 9068,29 & 9321,29 & 9528,79 & 3651,05 & 4054,55 & 8815,29 & 9068,29 & 9321,29 & 9528,79 & 9818,79 \\
\hline & J6.6 & 3651,05 & 4054,55 & 8815,29 & 9148,79 & 9401,79 & 9654,79 & 9862,29 & 3799,55 & 4254,05 & 9148,79 & 9401,79 & 9654,79 & 9862,29 & 10152,29 \\
\hline & J6.7 & 3799,55 & 4254,05 & 9148,79 & 9482,29 & 9735,29 & 9988,29 & 10195,79 & 3948,05 & 4453,55 & 9482,29 & 9735,29 & 9988,29 & 10195,79 & 10485,79 \\
\hline & J6.8 & 3948,05 & 4453,55 & 9482,29 & 9735,29 & 9988,29 & 10195,79 & 10485,79 & 3998,54 & 4521,38 & 9595,68 & 9821,31 & 10074,31 & 10266,34 & 10584,39 \\
\hline
\end{tabular}

Menentukan q apabila job 1.1 dikerjakan terlebih dahulu :

$\mathrm{q} 1=\mathrm{t} 11=52,35$ menit

$\mathrm{q} 2=\mathrm{t} 11+\mathrm{t} 12=52,35+75,75=128,1$ menit

$\mathrm{q} 3=\mathrm{t} 11+\mathrm{t} 12+\mathrm{t} 13=52,35+75,75+0=128,1$ menit

$\mathrm{q} 4=\mathrm{t} 11+\mathrm{t} 12+\mathrm{t} 13+\mathrm{t} 14=52,35+75,75+0+0=128,1$ menit

$\mathrm{q} 5=\mathrm{t} 11+\mathrm{t} 12+\mathrm{t} 13+\mathrm{t} 14+\mathrm{t} 15=52,35+75,75+0+0+0=128,1$ menit

$\mathrm{q} 6=\mathrm{t} 11+\mathrm{t} 12+\mathrm{t} 13+\mathrm{t} 14+\mathrm{t} 15+\mathrm{t} 16=52,35+75,75+0+0+0+205,5=333,6$ menit

$\mathrm{q} 7=\mathrm{t} 11+\mathrm{t} 12+\mathrm{t} 13+\mathrm{t} 14+\mathrm{t} 15+\mathrm{t} 16+\mathrm{t} 17=52,35+75,75+0+0+0+205,5+280$

$=613,6$ menit

Menghitung nilai bi pada job 1.1

$$
\begin{aligned}
& b 1=q 1+\sum_{j \text { 灆 }} t j 1+\min _{j \in \sigma}\{t j 2+t j 3+t j 4+t j 5+t j 6+t j 7\} \\
& \mathrm{b} 1=52,35+(3946,19)+319,14=4317,68 \text { menit } \\
& b 2=q 2+\sum_{j \in \sigma} t j 2+\min _{j \in \sigma}\{t j 3+t j 4+t j 5+t j 6+t j 7\} \\
& \mathrm{b} 2=128,1+(5183,51)+265,68=5577,29 \text { menit } \\
& b 3=q 3+\sum_{j \in \sigma} t j 3+\min _{j \in \sigma}\{t j 4+t j 5+t j 6+t j\} \\
& \mathrm{b} 3=128,1+(7562,94)+192,28=7883,32 \text { menit } \\
& b 4=q 4+\sum_{j \in \sigma} t j 4+\min _{j \in \sigma}\{t j 5+t j 6+t j 7\} \\
& \mathrm{b} 4=128,1+(5474,92)+96,14=5699,16 \text { menit } \\
& b 5=q 5+\sum_{j \in \sigma} t j 5+\min _{j \in \sigma}\{t j 6+t j 7\} \\
& \mathrm{b} 5=128,1+(5474,92)+0=5603,02 \text { menit } \\
& b 6=q 6+\sum_{j \in \sigma} t j 6+\min _{j \in \sigma}\{t j 7\} \\
& \mathrm{b} 6=333,6+(5858,70)+0=6192,30 \text { menit } \\
& b 7=q 7+\sum_{j \in \sigma} t j 7 \\
& \mathrm{~b} 7=613,6+(8287,70)=8901,70 \text { menit }
\end{aligned}
$$


Dari Partial Sequence di atas didapat nilai B dari seluruh job nilai yang terkecil adalah job ke 2.8. Sehingga job ke 2.8 dikerjakan terlebih dahulu. Kemudian menentukan q untuk menentukan urutan berikutnya.

Iterasi 2

Apabila Job 1.1 dikerjakan setelah Job 2.8

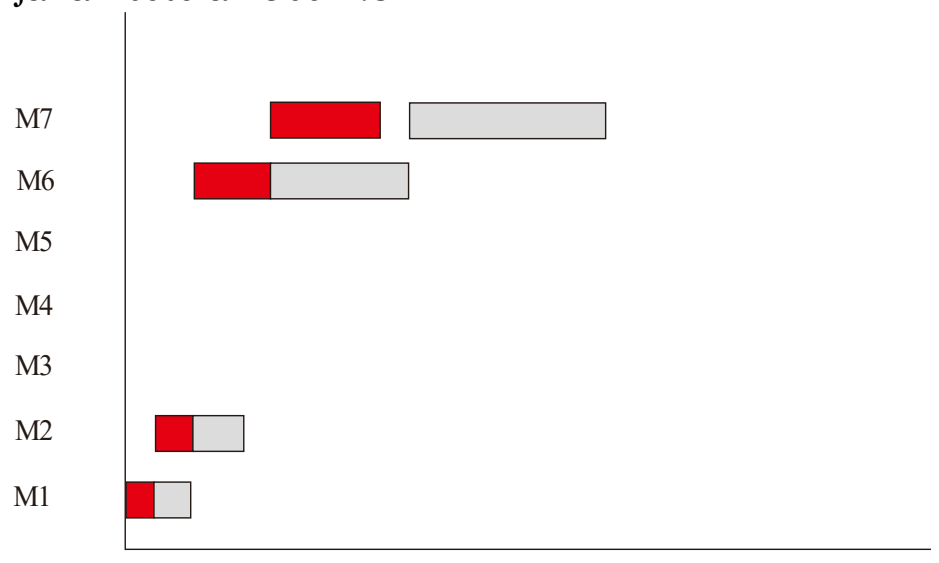

Job 2.8 Job 1.1

Gambar 1 Gantt Chart Iterasi 1

Dari Gambar 1 didapat nilai q untuk Job 1.1 yakni:

q1 $=92,36$ menit

$\mathrm{q} 2=169,22$ menit

$\mathrm{q} 3=169,22$ menit

$\mathrm{q} 4=169,22$ menit

q $5=169,22$ menit

$\mathrm{q} 6=374,72$ menit

$\mathrm{q} 7=655$ menit

Menghitung bi dari job 1.1

$b 1=q 1+\sum_{j \in \sigma} t j 1+\min _{j \in \sigma}\{t j 2+t j 3+t j 4+t j 5+t j 6+t j 7\}$

$\mathrm{b} 1=92,36+(3906)+356,06=4354,59$ menit

$b 2=q 2+\sum_{j \in \sigma} t j 2+\min _{j \in \sigma}\{t j 3+t j 4+t j 5+t j 6+t j 7\}$

$\mathrm{b} 2=169,22+(5130,045)+319,01=5618,27$ menit

$b 3=q 3+\sum_{j \in \sigma} t j 3+\min _{j \in \sigma}\{t j 4+t j 5+t j 6+t j 7\}$

b3 $=169,22+(7562,94)+192,28=7883,32$ menit

$b 4=q 4+\sum_{j \in \sigma} t j 4+\min _{j \in \sigma}\{t j 5+t j 6+t j 7\}$

$\mathrm{b} 4=169,22+(5474,92)+96,14=7828,30$ menit

$b 5=q 5+\sum_{j \in \sigma} t j 5+\min _{j \in \sigma}\{t j 6+t j 7\}$

Hasil Perhitungan secara lengkap dapat dilihat di tabel 3. 
Tabel 3 Partial Sequence Iterasi 2

\begin{tabular}{|c|c|c|c|c|c|c|c|c|c|c|c|c|c|c|c|}
\hline Batch & $\mathrm{q} 1$ & $\mathrm{q} 2$ & $\mathrm{q} 3$ & $\mathrm{q} 4$ & $\mathrm{q} 5$ & $\mathrm{q} 6$ & q7 & b1 & $\mathrm{b} 2$ & b3 & $\mathrm{b} 4$ & b5 & b6 & b7 & $\mathrm{B}$ \\
\hline J1.1 & 92,4 & 169,2 & 169,2 & 169,2 & 169,2 & 374,7 & 654,7 & 4354,6 & 5618,3 & 7828,3 & 5644,1 & 5644,1 & 6124,3 & 8785,8 & 8785,8 \\
\hline $\mathrm{J} 1.2$ & 92,4 & 169,2 & 169,2 & 169,2 & 169,2 & 374,7 & 654,7 & 4354,6 & 5618,3 & 7828,3 & 5644,1 & 5644,1 & 6124,3 & 8785,8 & 8785,8 \\
\hline J1.3 & 92,4 & 169,2 & 169,2 & 169,2 & 169,2 & 374,7 & 654,7 & 4354,6 & 5618,3 & 7828,3 & 5644,1 & 5644,1 & 6124,3 & 8785,8 & 8785,8 \\
\hline J1.4 & 92,4 & 169,2 & 169,2 & 169,2 & 169,2 & 374,7 & 654,7 & 4354,6 & 5618,3 & 7828,3 & 5644,1 & 5644,1 & 6124,3 & 8785,8 & 8785,8 \\
\hline J1.5 & 92,4 & 169,2 & 169,2 & 169,2 & 169,2 & 374,7 & 654,7 & 4354,6 & 5618,3 & 7828,3 & 5644,1 & 5644,1 & 6124,3 & 8785,8 & 8785,8 \\
\hline J1.6 & 92,4 & 169,2 & 169,2 & 169,2 & 169,2 & 374,7 & 654,7 & 4354,6 & 5618,3 & 7828,3 & 5644,1 & 5644,1 & 6124,3 & 8785,8 & 8785,8 \\
\hline J1.7 & 92,4 & 169,2 & 169,2 & 169,2 & 169,2 & 374,7 & 654,7 & 4354,6 & 5618,3 & 7828,3 & 5644,1 & 5644,1 & 6124,3 & 8785,8 & 8785,8 \\
\hline$*_{J} 1.8$ & 90,3 & 166,2 & 166,2 & 166,2 & 166,2 & 363,5 & 632,3 & 4354,6 & 5618,3 & 7921,4 & $\mathbf{5 7 3 7 , 3}$ & 5641,1 & 6121,3 & 8774,6 & 8774,6 \\
\hline J2.1 & 114,1 & 213,1 & 213,1 & 213,1 & 213,1 & 415,1 & 705,1 & 4354,6 & 5638,9 & 7968,3 & 5784,2 & 5688,0 & 6168,2 & 8826,2 & 8826,2 \\
\hline J2.2 & 114,1 & 213,1 & 213,1 & 213,1 & 213,1 & 415,1 & 705,1 & 4354,6 & 5638,9 & 7968,3 & 5784,2 & 5688,0 & 6168,2 & 8826,2 & 8826,2 \\
\hline J2.4 & 114,1 & 213,1 & 213,1 & 213,1 & 213,1 & 415,1 & 705,1 & 4354,6 & 5638,9 & 7968,3 & 5784,2 & 5688,0 & 6168,2 & 8826,2 & 8826,2 \\
\hline J2.5 & 114,1 & 213,1 & 213,1 & 213,1 & 213,1 & 415,1 & 705,1 & 4354,6 & 5638,9 & 7968,3 & 5784,2 & 5688,0 & 6168,2 & 8826,2 & 8826,2 \\
\hline J2.6 & 114,1 & 213,1 & 213,1 & 213,1 & 213,1 & 415,1 & 705,1 & 4354,6 & 5638,9 & 7968,3 & 5784,2 & 5688,0 & 6168,2 & 8826,2 & 8826,2 \\
\hline J2.7 & 114,1 & 213,1 & 213,1 & 213,1 & 213,1 & 415,1 & 705,1 & 4354,6 & 5638,9 & 7968,3 & 5784,2 & 5688,0 & 6168,2 & 8826,2 & 8826,2 \\
\hline \multicolumn{16}{|l|}{ J2.8 } \\
\hline J3.1 & 140,6 & 265,9 & 265,9 & 265,9 & 265,9 & 467,4 & 762,4 & 4354,6 & 5665,4 & 8021,1 & 5836,9 & 5740,8 & 6221,0 & 8878,5 & 8878,5 \\
\hline J3.2 & 140,6 & 265,9 & 265,9 & 265,9 & 265,9 & 467,4 & 762,4 & 4354,6 & 5665,4 & 8021,1 & 5836,9 & 5740,8 & 6221,0 & 8878,5 & 8878,5 \\
\hline J3.3 & 140,6 & 265,9 & 265,9 & 265,9 & 265,9 & 467,4 & 762,4 & 4354,6 & 5665,4 & 8021,1 & 5836,9 & 5740,8 & 6221,0 & 8878,5 & 8878,5 \\
\hline J3.4 & 140,6 & 265,9 & 265,9 & 265,9 & 265,9 & 467,4 & 762,4 & 4354,6 & 5665,4 & 8021,1 & 5836,9 & 5740,8 & 6221,0 & 8878,5 & 8878,5 \\
\hline J3.5 & 140,6 & 265,9 & 265,9 & 265,9 & 265,9 & 467,4 & 762,4 & 4354,6 & 5665,4 & 8021,1 & 5836,9 & 5740,8 & 6221,0 & 8878,5 & 8878,5 \\
\hline J3.7 & 126,5 & 234,2 & 234,2 & 234,2 & 234,2 & 407,5 & 661,2 & 4354,6 & 5651,3 & 7989,5 & 5805,3 & 5709,2 & 6189,4 & 8818,6 & 8818,6 \\
\hline $\mathrm{J} 4.1$ & 114,1 & 211,6 & 545,1 & 798,1 & 1051,1 & 1051,1 & 1051,1 & 4354,6 & 5638,9 & 7966,8 & 6116,2 & 6273,0 & 7006,2 & 9462,2 & 9462,2 \\
\hline $\mathrm{J} 4.2$ & 114,1 & 211,6 & 545,1 & 798,1 & 1051,1 & 1051,1 & 1051,1 & 4354,6 & 5638,9 & 7966,8 & 6116,2 & 6273,0 & 7006,2 & 9462,2 & 9462,2 \\
\hline $\mathrm{J} 4.3$ & 114,1 & 211,6 & 545,1 & 798,1 & 1051,1 & 1051,1 & 1051,1 & 4354,6 & 5638,9 & 7966,8 & 6116,2 & 6273,0 & 7006,2 & 9462,2 & 9462,2 \\
\hline J4.4 & 114,1 & 211,6 & 545,1 & 798,1 & 1051,1 & 1051,1 & 1051,1 & 4354,6 & 5638,9 & 7966,8 & 6116,2 & 6273,0 & 7006,2 & 9462,2 & 9462,2 \\
\hline $\mathrm{J} 4.5$ & 114,1 & 211,6 & 545,1 & 798,1 & 1051,1 & 1051,1 & 1051,1 & 4354,6 & 5638,9 & 7966,8 & 6116,2 & 6273,0 & 7006,2 & 9462,2 & 9462,2 \\
\hline J4.6 & 114,1 & 211,6 & 545,1 & 798,1 & 1051,1 & 1051,1 & 1051,1 & 4354,6 & 5638,9 & 7966,8 & 6116,2 & 6273,0 & 7006,2 & 9462,2 & 9462,2 \\
\hline $\mathrm{J} 4.7$ & 114,1 & 211,6 & 545,1 & 798,1 & 1051,1 & 1051,1 & 1051,1 & 4354,6 & 5638,9 & 7966,8 & 6116,2 & 6273,0 & 7006,2 & 9462,2 & 9462,2 \\
\hline $\mathrm{J} 4.8$ & 68,2 & 130,5 & 257,3 & 353,4 & 449,5 & 449,5 & 449,5 & 4537,3 & 5765,3 & 8159,5 & 5964,9 & 5828,3 & 6404,7 & 8860,6 & 8860,6 \\
\hline J5.1 & 140,6 & 265,9 & 649,4 & 902,4 & 1155,4 & 1155,4 & 1155,4 & 4354,6 & 5665,4 & 8021,1 & 6220,4 & 6377,3 & 7110,5 & 9566,5 & 9566,5 \\
\hline J5.2 & 140,6 & 265,9 & 649,4 & 902,4 & 1155,4 & 1155,4 & 1155,4 & 4354,6 & 5665,4 & 8021,1 & 6220,4 & 6377,3 & 7110,5 & 9566,5 & 9566,5 \\
\hline J5.3 & 140,6 & 265,9 & 649,4 & 902,4 & 1155,4 & 1155,4 & 1155,4 & 4354,6 & 5665,4 & 8021,1 & 6220,4 & 6377,3 & 7110,5 & 9566,5 & 9566,5 \\
\hline J5.4 & 140,6 & 265,9 & 649,4 & 902,4 & 1155,4 & 1155,4 & 1155,4 & 4354,6 & 5665,4 & 8021,1 & 6220,4 & 6377,3 & 7110,5 & 9566,5 & 9566,5 \\
\hline J5.5 & 140,6 & 265,9 & 649,4 & 902,4 & 1155,4 & 1155,4 & 1155,4 & 4354,6 & 5665,4 & 8021,1 & 6220,4 & 6377,3 & 7110,5 & 9566,5 & 9566,5 \\
\hline J5.6 & 140,6 & 265,9 & 649,4 & 902,4 & 1155,4 & 1155,4 & 1155,4 & 4354,6 & 5665,4 & 8021,1 & 6220,4 & 6377,3 & 7110,5 & 9566,5 & 9566,5 \\
\hline J5.7 & 132,6 & 247,8 & 600,6 & 833,4 & 1066,1 & 1066,1 & 1066,1 & 4354,6 & 5657,4 & 8003,0 & 6171,7 & 6308,3 & 7021,3 & 9477,2 & 9477,2 \\
\hline J6.1 & 188,5 & 388,0 & 721,5 & 974,5 & 1227,5 & 1435,0 & 1725,0 & 4354,6 & 5713,3 & 8143,2 & 6292,6 & 6449,4 & 7182,6 & 9846,1 & 9846,1 \\
\hline $\mathrm{J} 6.2$ & 188,5 & 388,0 & 721,5 & 974,5 & 1227,5 & 1435,0 & 1725,0 & 4354,6 & 5713,3 & 8143,2 & 6292,6 & 6449,4 & 7182,6 & 9846,1 & 9846,1 \\
\hline J6.3 & 188,5 & 388,0 & 721,5 & 974,5 & 1227,5 & 1435,0 & 1725,0 & 4354,6 & 5713,3 & 8143,2 & 6292,6 & 6449,4 & 7182,6 & 9846,1 & 9846,1 \\
\hline
\end{tabular}




\begin{tabular}{|c|c|c|c|c|c|c|c|c|c|c|c|c|c|c|c|}
\hline J6.4 & 188,5 & 388,0 & 721,5 & 974,5 & 1227,5 & 1435,0 & 1725,0 & 4354,6 & 5713,3 & 8143,2 & 6292,6 & 6449,4 & 7182,6 & 9846,1 & 9846,1 \\
\hline J6.5 & 188,5 & 388,0 & 721,5 & 974,5 & 1227,5 & 1435,0 & 1725,0 & 4354,6 & 5713,3 & 8143,2 & 6292,6 & 6449,4 & 7182,6 & 9846,1 & 9846,1 \\
\hline J6.6 & 188,5 & 388,0 & 721,5 & 974,5 & 1227,5 & 1435,0 & 1725,0 & 4354,6 & 5713,3 & 8143,2 & 6292,6 & 6449,4 & 7182,6 & 9846,1 & 9846,1 \\
\hline J6.7 & 188,5 & 388,0 & 721,5 & 974,5 & 1227,5 & 1435,0 & 1725,0 & 4354,6 & 5713,3 & 8143,2 & 6292,6 & 6449,4 & 7182,6 & 9846,1 & 9846,1 \\
\hline J6.8 & 90,5 & 161,3 & 274,7 & 360,7 & 446,7 & 517,3 & 615,9 & 4354,6 & 5618,3 & 7916,5 & 5845,8 & 5835,6 & 6401,9 & 8928,4 & 8928,4 \\
\hline
\end{tabular}

${ }^{*}$ J1.8 Job yang terpilih pada iterasi 2

Pada tabel 4 dapat diketahui job yang terpilih adalah job 1.8 maka job 1.8 akan dikerjakan setelah job 2.8, perhitungan dilakukan terus sampai pada iterasi ke 44 .

Tabel 4 Hasil Rekapan Partial Sequence Sampaim Iterasi ke-44

\begin{tabular}{|c|c|c|c|c|c|c|c|c|c|c|c|c|c|c|c|c|c|}
\hline Iterasi & Job & $\mathrm{q} 1$ & $q^{2}$ & $\mathrm{q}^{3}$ & $q 4$ & $q^{5}$ & q6 & $\mathrm{q}^{7}$ & $\mathrm{bl}$ & $\mathrm{b} 2$ & b3 & $\mathrm{b} 4$ & $\mathrm{~b} 5$ & $\mathrm{~b} 6$ & $\mathrm{~b} 7$ & $B$ & Iob Terpilih \\
\hline \multirow{7}{*}{1} & $\mathrm{~J} 1.1$ & 52,35 & 128,1 & 128,1 & 128,1 & 128,1 & 333,6 & 613,6 & 4317,68 & 5577,29 & 7883,32 & 5699,16 & 5603,02 & 6192,3 & 8901,3 & 8901,3 & \multirow{7}{*}{$\mathrm{J} 2.8$} \\
\hline & . & . & . & . & . & . & . & . & . & . & . & . & . & . & . & . & \\
\hline & . & . & . & . & . & . & . & . & . & . & . & . & . & . & . & . & \\
\hline & $\mathrm{J} 2.8$ & 40,014 & 93,474 & \begin{tabular}{|l|}
93,474 \\
\end{tabular} & 93,474 & \begin{tabular}{|l|}
93,474 \\
\end{tabular} & 202,554 & 359,154 & 4354,6 & 5618,28 & 7848,69 & 5664,53 & 5568,39 & 6157,67 & 8770,25 & 8770,3 & \\
\hline & . & . & . & . & . & . & . & . & . & . & . & . & . & . & . & . & \\
\hline & . & . & . & . & . & . & . & . & . & . & . & . & . & . & . & . & \\
\hline & $\mathrm{J} 6.8$ & 50,49 & 118,32 & 231,71 & 317,73 & 403,75 & 474,3 & 572,9 & 4317,68 & 5575,43 & 7873,54 & 5802,77 & 5792,65 & 6467,95 & 9042 & 9042 & \\
\hline \multirow{8}{*}{2} & $\mathrm{~J} 2.8$ & & & & & & & & & & & & & & & & \multirow{8}{*}{ J1.8 } \\
\hline & $\mathrm{J} 1.1$ & 92,364 & 169,224 & 169,224 & 169,224 & 169,224 & 374,724 & 654,724 & 4354,6 & 5618,28 & 7828,3 & 5644,14 & 5644,14 & 6124,34 & 8785,82 & 8785,8 & \\
\hline & . & . & . & . & . & . & . & . & . & . & . & . & . & . & . & . & \\
\hline & . & . & . & . & . & . & . & . & . & . & . & . & . & . & . & . & \\
\hline & J1.8 & 90,27 & 166,194 & 166,194 & 166,194 & 166,194 & 363,474 & 632,274 & 4354,6 & 5618,28 & 7921,41 & 5737,25 & 5641,11 & 6121,31 & 8774,57 & 8774,6 & \\
\hline & . & . & . & . & . & . & . & . & . & . & . & . & . & . & . & . & \\
\hline & . & . & . & . & . & . & . & . & . & . & & . & . & . & . & & \\
\hline & J6.8 & 90,504 & 161,304 & 274,694 & 360,714 & 446,734 & 517,284 & 615,884 & 4354,6 & 5618,28 & 7916,52 & 5845,75 & 5835,63 & 6401,85 & 8928,38 & 8928,4 & \\
\hline . & . & . & . & . & . & . & . & . & . & . & . & . & . & . & . & . & . \\
\hline . & . & . & . & . & . & . & . & . & . & . & . & . & . & . & . & . & . \\
\hline \multirow{6}{*}{44} & $\mathrm{~J} 2.8-\mathrm{J} 1.8-\mathrm{J} 2.1-\mathrm{J} 2.2-\mathrm{J} 2.3-\mathrm{J} 6.8-\mathrm{J} 3.7-\mathrm{J} 2.4-$ & \multirow{6}{*}{3965,38} & \multirow{6}{*}{5260,22} & \multirow{6}{*}{8791,22} & \multirow{6}{*}{9044,22} & \multirow{6}{*}{9297,22} & \multirow{6}{*}{9504,72} & \multirow{6}{*}{9794,72} & \multirow{6}{*}{4321,44} & \multirow{6}{*}{5607,39} & \multirow{6}{*}{9020,55} & \multirow{6}{*}{9267,09} & \multirow{6}{*}{9393,36} & \multirow{6}{*}{9600,86} & \multirow{6}{*}{9794,72} & \multirow{6}{*}{9794,7} & \multirow{6}{*}{$\mathrm{J} 6.8$} \\
\hline & J2.5-J1.1-J1.2-J1.3-J1.4-J4.1-J5.7-J2.6- & & & & & & & & & & & & & & & & \\
\hline & J2.7-J1.5-J1.6-J1.7-J3.1-J3.2-J4.2-J3.3- & & & & & & & & & & & & & & & & \\
\hline & J3.4-J4.3-J3.5-J3.6-J4.4-J4.5-J4.6-J4.7- & & & & & & & & & & & & & & & & \\
\hline & J5.1-J5.2-J5.3-J5.4-J5.5-J5.6-J6.1-J6.2- & & & & & & & & & & & & & & & & \\
\hline & J6.3-J6.4-J6.5-J6.6-J6.7-J4.8 & & & & & & & & & & & & & & & & \\
\hline
\end{tabular}

\section{Simpulan}

Urutan pengerjaan yang dihasilkan dengan metode Branch and Bound adalah Job 2.8, Job 1.8, Job 2.1, Job 2.2, Job 2.3, Job 6.8, Job 3.7, Job 2.4, Job 2.5, Job 1.1, Job 1.2, Job 1.3, Job 1.4, Job 4.1, Job 5.7, Job 2.6, Job 2.7, Job 1.5, Job 1.6, Job 1.7, Job 3.1, Job 3.2, Job 4.2, Job 3.3, Job 3.4, Job 4.3, Job 3.5, Job 3.6, Job 4.4, Job 4.5, Job 4.6, Job 4.7, Job 5.1, Job 5.2, Job 5.3, Job 5.4, Job 5.5, Job 5.6, Job 6.1, Job 6.2, Job 6.3, Job 6.4, Job 6.5, Job 6.6, Job 6.7, dan Job 4.8. Hasil perhitungan dengan metode usulan dapat dibandingkan dengan metode perusahaan. Penjadwalan dengan metode perusahaan memiliki nilai makespan sebesar 10584,385 menit, sedangkan jika menggunakan metode Branch and Bound memiliki nilai makespan sebesar 9794,719 menit. Metode Branch and Bound lebih baik jika dibanding dengan metode perusahaan, dengan selisih waktu sebesar 789,66 menit atau 1,8 hari lebih cepat dari pada metode perusahaan. Atau dengan kata lain 7,46 \% lebih cepat dibanding metode perusahaan. Oleh karena itu, metode yang diusulkan untuk perusahaan guna meminimalkan waktu makespan-nya yaitu dengan menggunakan metode Branch and Bound. 


\section{Referensi}

[1] V. A. Sari, D. D. Damayanti, and W. Juliani, "Penjadwalan Produksi Dengan Mempertimbangkan Ukuran Lot Transfer Batch Untuk Minimasi Makespan Komponen Isolating Cock Di Pt Pindad," Jurnal Rekayasa Sistem \& Industri (JRSI), vol. 2, pp. 74-81, 2015.

[2] M. Haming and M. Nurnajamuddin, Manajemen Produksi Modern. Jakarta: Bumi Aksara, 2007.

[3] K. R. Baker and D. Trietsch, Principles of sequencing and scheduling: John Wiley \& Sons, 2013.

[4] I. Masudin, D. M. Utama, and F. Susastro, "Penjadwalan Flowshop Menggunakan Algoritma Nawaz Enscore HaM," Jurnal Ilmiah Teknik Industri, vol. 13, pp. 54$59,2014$.

[5] M. Firdaus, I. Masudin, and D. M. Utama, "Penjadwalan Flowshop Dengan Menggunakan Simulated Annealing," Spektrum Industri, vol. 13, 2015.

[6] Ł. Kruk, J. Lehoczky, and S. Shreve, "Second order approximation for the customer time in queue distribution under the FIFO service discipline," Annales Universitatis Mariae Curie-Sklodowska, sectio AI-Informatica, vol. 1, pp. 1-12, 2015.

[7] M. Husen, I. Masudin, and D. M. Utama, "Penjadwalan Job Shop Statik Dengan Metode Simulated Annealing Untuk Meminimasi Waktu Makespan," Spektrum Industri, vol. 13, 2015.

[8] Yusrofi, A. K. Garside, and D. Marsetiya U, "Penjadwalan Job Shop dengan Menggunakan Algoritma Penjadwalan Non Delay untuk Meminimasi Makespan Studi Kasus di Mebel Rieki," Teknik Industri, Universitas Muhammadiyah Malang, Malang, 2015.

[9] S. Harto, A. K. Garside, and D. M. Utama, "penjadwalan produksi menggunakan algoritma jadwal non delay untuk meminimalkan makespan studi kasus di cv. Bima mebel," Spektrum Industri, vol. 14, 2016.

[10] S. Altmeyer, S. M. Sundharam, and N. Navet, "The case for FIFO real-time scheduling," University of Luxembourg2016.

[11] R. Ginting, Penjadwalan Mesin. Medan: Graha Ilmu, 2009.

[12] K. R. Baker, Introduction to sequencing and scheduling: John Wiley \& Sons, 1974. 